\title{
Optimal Sizing of an Islanded Micro-grid for an area in north-west Iran Using Particle Swarm Optimization Based on Reliability Concept
}

\author{
H. Hassanzadehfard ${ }^{1, *}$, S.M.Moghaddas-Tafreshi ${ }^{1}$, S.M.Hakimi ${ }^{1}$ \\ ${ }^{1}$ Faculty of Electrical Engineering, Khajeh Nasir Toosi University, Iran, Tehran \\ *Corresponding author.Tel: +989124798639 Fax:+982188462066,E-mail: sm_hakimi@ieee.org
}

\begin{abstract}
In islanded micro-grid design, a proper Distributed Energy Resource (DER) selection, sizing and effective coordination between resources are important and challenging optimization tasks. The types and sizes of renewable energy sources such as wind turbines, photovoltaic panels, fuel cell and the capacities of battery bank and the other distributed generators must be optimized in islanded micro-grid design. In this paper, the problem is formulated as a nonlinear integer minimization problem which minimizes the sum of the total capital, operational and maintenance and replacement cost of DERs, subject to constraints such as energy limits of each DER. This paper proposes Particle Swarm Optimization (PSO) for solving this minimization problem. The proposed methodology was used to design micro-grid for northwest of Iran. The simulation studies have shown that the proposed methodology provides excellent convergence and feasible optimum solution for sizing of islanded micro-grids using particle swarm optimization. In this paper some notions of reliability are considered for micro-grid, and the effect of reliability on total cost of micro-grid is evaluated.
\end{abstract}

Keywords: Micro-grid, Optimal sizing, Particle swarm optimization, Reliability

\section{Nomenclature}

$P_{\text {wind }}$ power generated by wind turbines....... kW

$P_{P V}$ power generated by $P V$ generators ....... kW

$P_{F C}$ power generated by fuel cells ............... kW

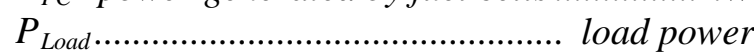

$\begin{array}{ll}E_{\text {bat }} & \text { stored energy in battery banks .................. kWh } \\ R & \text { lifetime of project ................................ year } \\ L & \text { lifetime of each component .................. year } \\ \text { ir } & \text { Htwerest rate .............................................. \% }\end{array}$

\section{Introduction}

The increase in penetration of distributed generation depth and the presence of multiple distributed generators in electrical proximity to one another have brought about the concept of the micro-grid [1, 2]. Micro-grids comprise low voltage distribution systems with distributed energy sources, storage devices, and controllable loads, operated either islanded or connected to the main power grid in a controlled, coordinated way. Refs. [3, 4] introduce the benefits of micro-grid, such as, enhance local reliability, reduce feeder losses, support local voltages, provide increased efficiency through using waste heat combined heat and power, voltage sag correction or provide uninterruptible power supply functions. Proper selection of distributed energy resources and optimal sizing of them are important and challenging tasks in the designing of islanded micro-grids [5] because the coordination among distributed energy resources is very complicated. The problem can be formulated as a nonlinear integer optimization problem which can be solved by a suitable optimizing methodology. Our aim is to minimize the total costs of the system such that the demand is met. For standalone hybrid wind/PV power systems, a typical tangent method is used to fix the size of wind generator and optimize the size of PV panels and the capacity of batteries [5, 7]. Several research works have been done for selecting the parameters such as the size of wind generators, the size of PV panels and the capacity of batteries but the decision variables collectively taken without any optimizing methodologies [5- 12]. Recently, a genetic algorithm for the concerned problem has been proposed by $\mathrm{Xu}$ et al. [13] where genetic algorithm optimizes the size of wind generators, the size of PV panels and the capacity of batteries as decision variables. Although this method provides a better performance in comparison to the previous literature, 
it is necessary to find a flexible generalized methodology for any kind of micro-grid designing with higher computational efficiency.

In this paper, the optimal sizing of a wind-PV-fuel cell-battery bank in micro-grid is considered. The optimization is carried out via Particle Swarm Optimization (PSO) algorithm. Generation of hydrogen by the reformer causes a higher reliability for the system.

First, we consider the micro-grid. And then the cost of the system presented by an objective function. Finally some simulation results are presented. This study is performed for Ganje site in northwest of Iran. It is located in a village with a population of 800 .

\section{Description of the micro-grid components}

\subsection{Wind turbine}

The power of the wind turbine is described in terms of the wind speed by Ref [16]:

$\left\{\begin{array}{lr}0 & V<V_{\text {cut-in }}, V>V_{\text {cut-off }} \\ P_{\text {rated }} \times\left(\left(V-V_{\text {cut-in }}\right) /\left(V_{\text {rated }}-V_{\text {cut-in }}\right)\right)^{3} & V_{\text {cut-in }} \leq V<V_{\text {rated }} \\ P_{\text {rated }} & V_{\text {rated }} \leq V \leq V_{\text {cut-off }}\end{array}\right.$

In which $V_{\text {cut-in }}, V_{\text {cut-off }}, V, V_{\text {rated }}$ and $P_{\text {rated }}$ are cut-in wind speed [m/s], cut-out wind speed $[\mathrm{m} / \mathrm{s}]$, wind speed $[\mathrm{m} / \mathrm{s}]$, nominal wind speed $[\mathrm{m} / \mathrm{s}]$ and the rated power of wind turbine $[\mathrm{kW}]$ respectively. In this analysis, each wind turbine has a rated capacity of $1 \mathrm{~kW}$. Cost of one unit is considered 2500\$, while replacement and maintenance cost are taken as $1500 \$$ and $\$ 75 /$ year. Lifetime of a turbine is taken to be 20 years [14].

\section{2. $P V$}

The output power of the PV generator $P_{P V}$, can be calculated according to the following equation:

$$
P_{P V}=\eta_{g} * N * A_{m} * G_{t}
$$

Where $\eta_{g}$ is the instantaneous PV generator efficiency, $A_{m}$ is the area of a single module used in a system $\left(\mathrm{m}^{2}\right), G_{t}$ is the global irradiance incident on the titled plane $\left(\mathrm{W} / \mathrm{m}^{2}\right)$ and $\mathrm{N}$ is the number of modules. In this analysis, each PV generator has a rated power of $1 \mathrm{~kW}$. Cost of one unit considered is $6000 \$$ while replacement and maintenance cost are taken as $5000 \$$ and $0 \$ /$ year respectively. Lifetime of a PV generator is taken to be 20 years [14].

\subsection{Fuel cell}

Proton exchange membrane (PEM) fuel cell is an environmentally clean power generator which combines hydrogen fuel with oxygen from air to produce electricity.

The capital cost, replacement cost and operational cost are taken as $3 \$ \mathrm{k}, 2.5 \$ \mathrm{k}$ and $175 \$$ /year for a 1-kw system, respectively. Fuel cell's lifetime is considered to be 5 years [14].

\subsection{Battery storage}

At any hour the state of battery is related to the previous state of charge and to the energy production and consumption situation of the system during the time from $t-1$ to $t$.

In all cases the storage battery capacity is subject to the following constraints: 


$$
E_{b a t \min } \prec E_{b a t}(t) \prec E_{b a t \max }
$$

Where $E_{\text {batmax }}$ and $E_{\text {batmin }}$ are the maximum and minimum allowable storage capacities.

$E_{b a t \min }$ is determined by the maximum allowable depth of battery discharge (DOD) as follows:

$E_{b a t \min }=(1-D O D) * E_{b a t \max }$

In this analysis, each battery bank capacity is 552Ah. Cost of each battery is considered 264\$ while replacement and maintenance costs are taken as $260 \$$ and $2.64 \$ /$ year. Lifetime of a battery is taken to be 3 years [14].

\section{System modeling}

The micro-grid consists of some wind turbines, PV arrays, fuel cells, reformers and battery banks (Fig. 1). Natural gas is used to produce fuel cells' required hydrogen.

It is desirable that the system meets the demand, the costs are minimized and the components have optimal sizes.

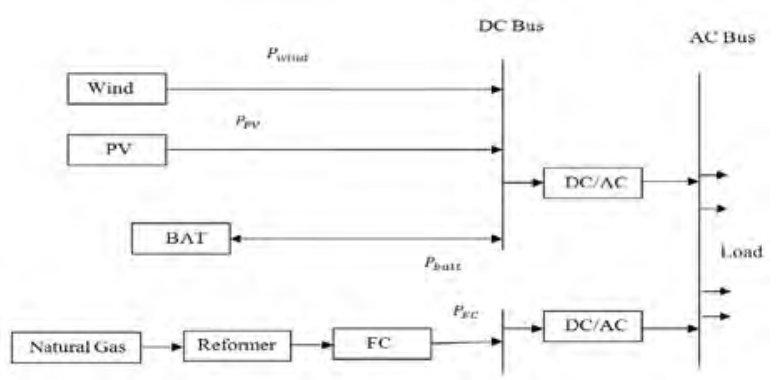

Fig.1. Schematic diagram of micro-grid

\subsection{Strategy}

We consider three situations for the system: A. generation power produced by renewable energy (wind + PV) meets demand, B. over generation and C. over demand.

\subsubsection{Power generation produced by wind and PV meets demand}

In this situation the power generated by the wind turbine plus the power produced by the PV array is equal to the demand $\left(P_{\text {wind }}(t)+P_{P V}(t)=\left(P_{\text {Load }}(t) / \eta_{\text {conv }}\right)\right)$, hence:

$E_{b a t}(t)=E_{b a t}(t-1), P_{F C}(t)=0$

It is notable that the time steps $\Delta \mathrm{t}$ are taken to be 1 hour in this study.

\subsubsection{Over generation}

The produced power of the wind turbine plus power produced by the PV array are more than the demand $\left(P_{\text {wind }}(t)+P_{P V}(t) \succ\left(P_{\text {Load }}(t) / \eta_{\text {conv }}\right)\right)$.

The excess power is utilized for charging the batteries:

$$
E_{\text {bat }}(t)=E_{\text {bat }}(t-1)+\left(P_{\text {wind }}(t)+P_{P V}(t)-P_{\text {Load }}(t) / \eta_{\text {conv }}\right) * \Delta t * \eta_{\text {cha }}, P_{F C}(t)=0
$$




\subsubsection{Over demand}

The demand is more than the power generated by the wind turbines and power produced by the PV array $\left(P_{\text {wind }}(t)+P_{P V}(t) \prec\left(P_{\text {Load }}(t) / \eta_{\text {conv }}\right)\right)$.

In this situation we have two cases:

a. Available battery banks' energy and power generation of wind turbine plus PV array can meet demand $\left(P_{\text {wind }}(t)+P_{P V}(t)+\left(E_{\text {bat }}(t)-E_{\text {bat min }}\right) * \eta_{\text {dech }} / \Delta t \succ\left(P_{\text {Load }}(t) / \eta_{\text {conv }}\right)\right)$.

$E_{b a t}(t)=E_{b a t}(t-1)+\left(P_{\text {wind }}(t)+P_{P V}(t)-P_{\text {Load }}(t) / \eta_{\text {conv }}\right) * \Delta t / \eta_{\text {dech }}, P_{F C}(t)=0$

b. Available battery banks' energy and power generation of wind turbine plus PV array can not meet demand:

In this situation the battery banks are completely discharged and the energy in the battery banks is equal to $E_{b a t \min }$. In this state, load requirements are supplied from the fuel cell:

$$
E_{\text {bat }}(t)=E_{\text {bat min }}, \quad P_{F C}(t)=\left(P_{\text {Load }}(t) / \eta_{\text {conv }}\right)-P_{P V}(t)-P_{\text {wind }}(t)-\left(E_{\text {bat }}(t)-E_{\text {bat min }}\right) * \eta_{\text {dech }} / \Delta t
$$

\subsection{System's cost}

In this paper we consider the capital and replacement costs, the operation and maintenance costs of each component of micro-grid.

We choose Net Present Cost (NPC) for calculation of system's cost.

\subsubsection{Net Present Cost}

The Net Present Cost (NPC) of each component is defined as [15]:

$$
\begin{aligned}
& N P C=N *(\text { capital_cost }+ \text { replacement_cost } * K+\text { operation \& ma int enance_cost } \\
& * \frac{1}{C R F(\text { ir }, R)}
\end{aligned}
$$

$C R F(i r, R)=\frac{i r^{*}(1+i r)^{R}}{(1+i r)^{R}-1}, K=\sum_{n=1}^{y} \frac{1}{(1+i r)^{L^{*} n}}$

$\mathrm{L}$ is the lifetime and $\mathrm{N}$ is the optimal number of each component.

\subsubsection{The objective function}

The objective function is the sum of all net present costs [16]:

$$
N P C=N P C_{\text {wind }}+N P C_{P V}+N P C_{\text {battery }}+N P C_{F C}+N P C_{\text {ref }}+N P C_{c o n v}
$$

The objective function must be minimized, such as minimization is done by PSO algorithm in this paper.

\section{Simulation results}

Lifetime of the project is 20 years. In this article, the optimum combination of the micro-grid considered shown in Fig. 1 is calculated. The system data consists of the annual wind data and 
solar radiation which belong to a region in northwest of Iran. The load curve which is actually an IEEE standard curve with $500 \mathrm{~kW}$ peak, the yearly wind speed and solar radiation are showed in fig.2. For the sake of simplicity, we have considered the weekly mean in input data in our simulation. The data is the wind velocity and the demand in every one hour in a day. So, an average of the input data in each hour is calculated during a week. The power of the wind turbine and PV array could be derived by Eq. (1.2) from the wind speed and solar radiation data. The optimal size of wind turbine, PV array, battery bank and Fuel cell are shown in table.1. Fig.3. shows the output power of wind turbine, PV array, fuel cell and Energy of battery storages. We see that at the time 940, fuel cell injects power to the microgrid. Where the available battery storage energy is equal to minimum allowable storage capacity and output power of PV array is equal to zero. Also output power of wind turbine does not satisfy the micro-grid's demand, so fuel cell injects power to the micro-grid in order to compensate load requirements. Fig.4. Shows the system costs in terms of the iterations.

Table 1. Optimal size of each component.

\begin{tabular}{ccccc}
\hline $\begin{array}{c}\text { Number } \\
\text { Wind turbine }\end{array}$ & Number PV array & $\begin{array}{c}\text { Number Battery } \\
\text { bank }\end{array}$ & $\begin{array}{c}\text { Number Fuel } \\
\text { cell }\end{array}$ & Total cost \$ \\
\hline 351 & 1758 & 4217 & 187 & $17.838 \mathrm{M}$ \\
\hline
\end{tabular}
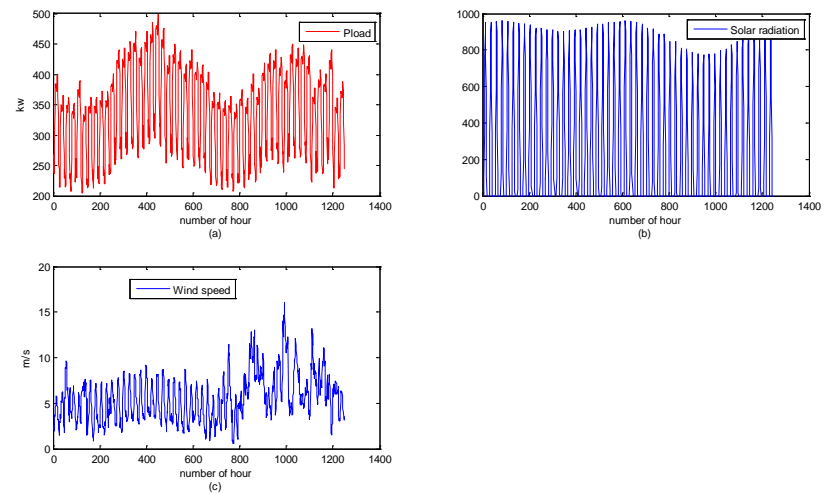

Fig. 2. (a). Load information. (b) Solar radiation information. (c) Wind speed information.
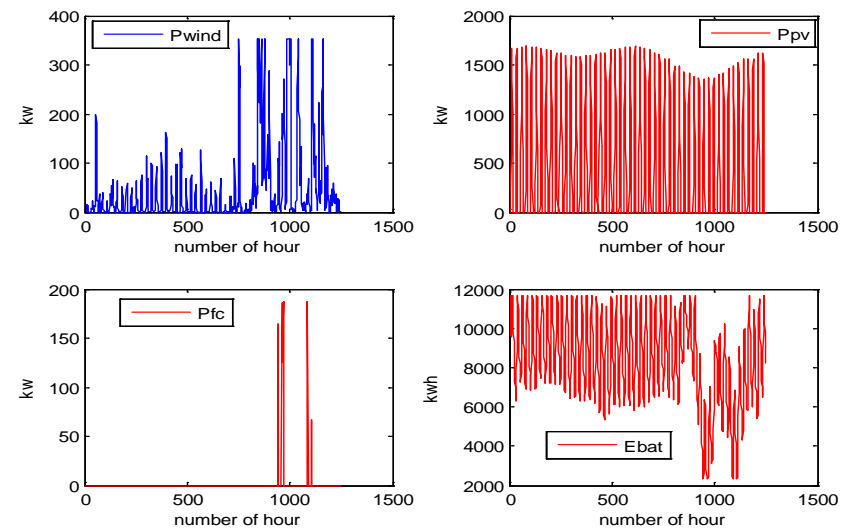

Fig. 3 (a) Output power of wind turbine. (b) Output power of PV array. (c) Output power of fuel cell. (d) Energy fluctuate of battery banks. 


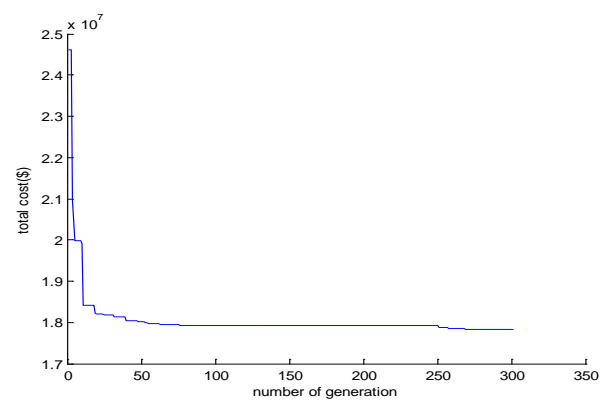

Fig. 4. The optimal cost of micro-grid in terms of the iterations

\subsection{Effect of the capital cost of PV arrays on simulation results}

In this section, the effect of capital cost of PV arrays, on the optimal size of each component and total cost of micro-grid is regarded. Table.2 shows that increasing the capital cost of the PV array causes the micro-grid costs to increase and the optimal size of PV array to reduce.

Table 2. Effect of capital cost of PV array.

\begin{tabular}{cccccc}
\hline Capital cost of PV unit & Wind turbine & PV array & Battery bank & Fuel cell & Total cost \$ \\
\hline 5000 & 337 & 1787 & 4154 & 193 & $16.149 \mathrm{M}$ \\
6000 & 351 & 1758 & 4217 & 187 & $17.838 \mathrm{M}$ \\
7000 & 383 & 1748 & 4263 & 172 & $19.558 \mathrm{M}$ \\
8000 & 523 & 1603 & 4732 & 106 & $20.646 \mathrm{M}$ \\
\hline
\end{tabular}

\section{Reliability}

Some notions of reliability are commonly used for systems with hourly demand and supply data. Loss of Load Expectation (LOLE), Loss of Energy Expectation (LOEE), Loss of Power Supply Probability (LPSP) and Equivalent Loss Factor (ELF) are some of them considered in this paper. ELF is described by:

$E L F=\frac{1}{N} \sum_{t=1}^{N} \frac{Q(t)}{D(t)}$

Where $D(t)$ is the total energy demand, $Q(t)$ is the loss-of-load and $N$ is the number of hours. The ELF contains information about both the number of outages and their magnitude. In this paper we regard that ELF should be lower than 0.01 [17].

\subsection{Simulation Result considering reliability parameters}

In this micro-grid when the power of fuel cell to support the demand is greater than the optimal size, $Q(t)$ is described by:

$Q(t)=P_{F C}(t)-N_{F C} * P_{\text {Fuel-Cell }}$

Where $N_{F C}$ is the optimum size and $P_{\text {Fuel-Cell }}$ is the rated power of fuel cell. The cost of electricity interruptions has been estimated. The value we use in our model is $5.6 \$ / \mathrm{kWh}$. Fig.5. depicts the flowchart of the algorithm simulating the micro-grid considering reliability. The optimal size of wind turbine, PV array, battery bank, fuel cell and the total cost of microgrid are shown in table. 3 . 


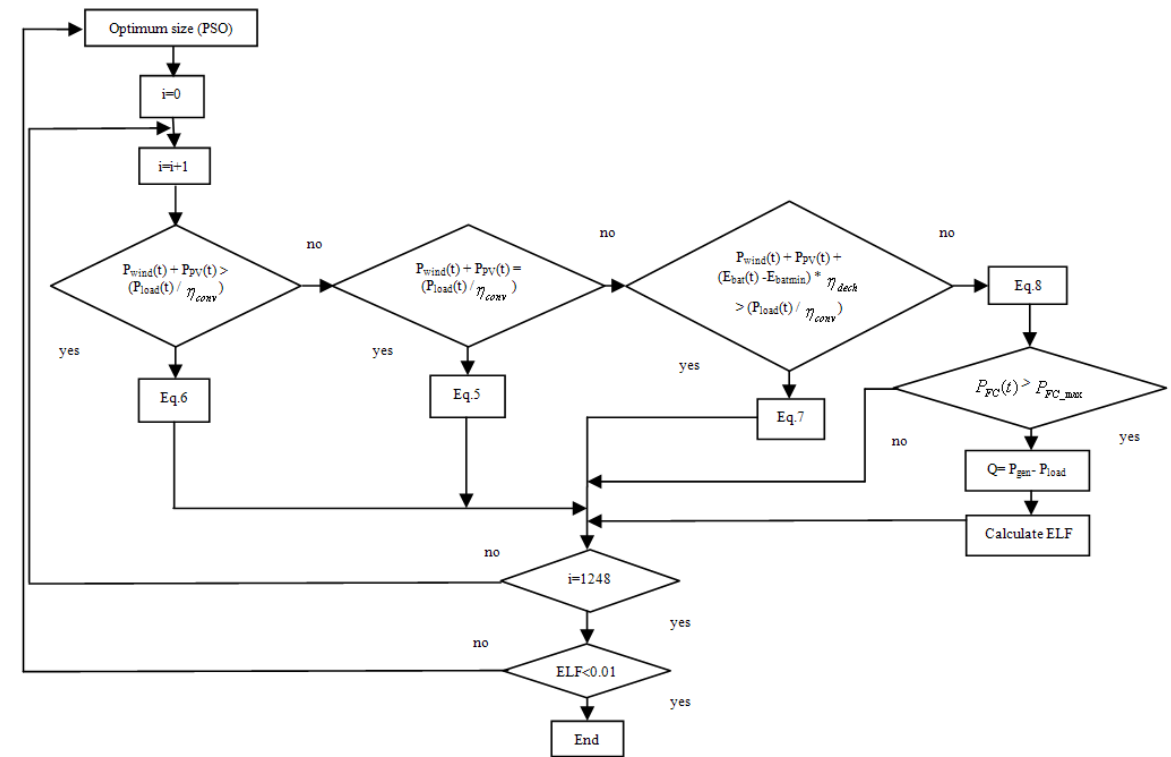

Fig.5. The flowchart of the algorithm simulating the micro-grid considering reliability.

Table.3. Optimal size of each component considering reliability parameters.

\begin{tabular}{ccccc}
\hline Wind turbine & PV array & Battery bank & Fuel cell & Total cost \$ \\
\hline 515 & 1660 & 3150 & 14 & $15.33 \mathrm{M}$ \\
\hline
\end{tabular}

Table.3 shows that considering reliability parameters such as ELF for micro-grid (some of loads in some hours are not satisfied) reduces the total cost of micro-grid. Figure 6 shows the loss of energy in each hour.

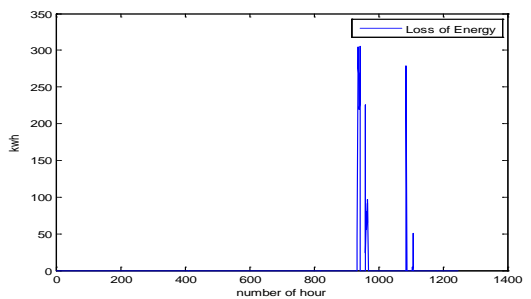

Fig. 6. Loss of energy in each hour.

We see that maximum loss of energy appears at the time between 900-1000. Where the available battery storage energy and output power of PV array to inject to the micro-grid is equal to zero. The value of some notions of reliability is shown in table. 4 . Table 4 shows that ELF is in the acceptable confine.

Table 4. The amount of some notions of reliability

\begin{tabular}{ccccc}
\hline LOLE $(\mathrm{hr} / \mathrm{yr})$ & LPSP & LOEE $(\mathrm{MWh} / \mathrm{yr})$ & ELF & Penalty \\
\hline 24 & $9.1098^{*} 10^{-3}$ & 3.8623 & $9.999 * 10^{-3}$ & $0.21235 \mathrm{M}$ \\
\hline
\end{tabular}

\section{Conclusion}

In this paper the optimal sizing and operation strategy of micro-grid are considered. The system consists of wind turbines, PV arrays, fuel cells, battery banks, reformers and DC/AC converters. The micro-grid used in this study has high reliability because fuel cells are as a backup for wind turbines and PV arrays. The main problem of renewable energy source is that they are dependent on environmental conditions. So they could not cover the demand 
perfectly. Entering storage component solves this problem significantly. In this study battery bank is used to cover the demand desirably. We assumed that in each hour micro-grid can interrupt loads subject to reliability constraint such as ELF. In this situation total cost of micro-grid reduces.

\section{References}

[1] R. Lasseter, A. Akhil, C. Marnay, J. Stephens, J. Dagle, R. Guttromson, A. Meliopoulos, R. yinger and J. Eto, "White paper on Integration of consortium Energy Resources. The CERTS MicroGrid Concept.”CERTS, CA, Rep.LBNL-50829, Apr.2002.

[2] MICROGRIDS: Large Scale integration of Micro-Generation to low Voltage Grids” EU contact ENK5-CT-2002-00610, Technical Annex, May 2002.

[3] Lasseter RH. MicroGrids. IEEE Power Eng Soc Transm Distrib Conf 2002(1):305-8.

[4] Marnay Chris, Venkataramanan Giri. Microgrids in the evolving electricity generation and delivery infrastructure. IEEE Power Eng Soc Gen Meet 2006:18-22.

[5] H. L. Willis and W. G. Scott, Distributed Power Generation: Planning and Evaluation, Marcel Dekker, New York, 2000.

[6] California Distributed Energy Resources Guide, Available at: http://www.energy.ca.gov/distgen/

[7] B. S. Borowy and Z. M. Salameh, "Methodology for Optimally Sizing the Combination of a Battery Bank and PV Array in a Wind/PV Hybrid System," IEEE Trans. On Energy Conversion, pp.367-375, 1996.

[8] M. A. Habib, S. A. M. Said, M. A. El-Hadidy and A. I. Zaharna," Optimization Procedure of Hybrid Photovoltaic Wind Energy System Energy," pp.919-929, 1999.

[9] J. K. Kaldellis, "Parametric Investigation Concerning Dimensions of a Stand-alone WindPower System," Applied Energy, pp.35-50, 2004.

[10]B. Ai, H. Yang, H. She and X. Liao, "Computer-aided Design of PV/wind Hybrid System," Renewable Energy, pp.1491-1512, 2003.

[11]M. A. Elhadidy and S. M. Shaahid, "Optimal Sizing of Battery Storage for Hybrid (wind+diesel) Power Systems," Renewable Energy, pp.77-86,1999.

[12]A. M. Al-Ashwal and I. S. Moghram, "Proportion Assessment of Combined PV-Wind Generating Systems," Renewable Energy. pp.43-51, 1997.

[13]D. Xu, L. Kang and B. Cao, "Optimal Sizing of Standalone Hybrid Wind/PV Power Systems Using Genetic Algorithms," Proc. of IEEE Canadian Conference on Electrical and Computer Engineering, Canada, pp. 1705-1708, 2005.

[14]M.J. Khan, M.T. Iqbal, "Pre-feasibility study of stand-alone hybridenergy systems for applications in Newfoundland", Renewable Energy 30 (2005) 835-854.

[15]<www.mahler-ags.com>

[16]Hakimi SM, Moghaddas-Tafreshi SM. "Unit sizing of a stand-alone hybrid power system using particle swarm optimization (PSO)". IEEE ICAL Aug 2007; 18-21:3107-12.

[17]Raquel S. Garcia, Daniel Weisser, "A wind-diesel system with hydrogen storage: Joint optimization of design and dispatch", Renewable Energy 31 (2006) 2296-2320. 